\title{
THE ANALYSIS OF COSTS RELATED TO BOVINE SPONGIFORM ENCEPHALOPATHY DISEASE OCCURRENCE IN THE CZECH RE- PUBLIC IN 2001-2014
}

\author{
Richard POSPÍŠIL ${ }^{1}$
}

Received May 20, 2015; accepted June 30, 2015. Delo je prispelo 20. maja 2015, sprejeto 30. junija 2015.

\begin{abstract}
The analysis of costs related to bovine spongiform encephalopathy disease occurrence in the Czech Republic in 2001-2014

This paper pays attention to analysis of the economic impacts of the bovine spongiform encephalopathy (BSE) occurrence in the Czech Republic, namely the financial compensations to the farmers whose herds had been affected and the costs of animal killing and carcass disposal in the rendering plant. Between February 2001 and the end of 2014, a total of 1879749 cows were examined and 30 cases of the BSE were detected. Consequently, 4243 cows in cohorts were killed and their carcasses were safely disposed of. The farmers whose herds had been affected were provided compensations for the losses suffered. The total of the compensations in this period reached EUR 7752 000. Of these, $83.3 \%$ (EUR 6458 000) were compensations for the value of the killed animals, $9.7 \%$ (EUR 752000) for the related costs, i.e., killing, safe disposal of carcasses and the examination for the BSE, and $6.9 \%$ (EUR $535000)$ for the losses due to non-materialised production. The average costs per 1 BSE-positive animal were EUR 258400 and the average costs per 1 cohort animal were EUR 1827 . In the rendering plant responsible for killing the infected and cohort animals and safely disposing of their carcasses, the total of 2342 tons of raw material was processed between March 2003 and 2009, and this cost EUR 363777 . The fact that there were only two last cases of the BSE in 2009 suggests a trend towards the disease eradication, which is in agreement with the situation in the other EU countries.
\end{abstract}

Key words: cattle / infectious diseases / bovine spongiform encephalopathy / BSE / economics / costs / financial compensation / Czech Republic

\section{Analiza stroškov, povezanih $z$ bovino spongiformno encefalo- patijo $v$ Češki republiki v obdobju 2001-2014}

Prispevek obravnava ekonomske posledice pojava bovine spongiformne encefalopatije (BSE) v Češki republiki, namreč denarna nadomestila rejcem, katerih črede so bile prizadete, ter stroške klanja živali in odstranitve klavnih trupov v kafileriji. Med februarjem 2001 in koncem leta 2014 je bilo testiranih $1,879.749$ goved in v 30 primerih je bil odkrit BSE. V čredah, kjer se je pojavil BSE, je bilo izločenih 4.243 živali. Kmetom, katerih črede so bile prizadete, so ponudili nadomestila za izgube, ki so jih utrpeli. Vsota nadomestil v tem času je dosegla znesek 7,752.000 evrov. Od tega je bilo 83,3\% (6,458.000 evrov) nadomestil za zaklane živali, 9,7\% (752.000 evrov) za s tem povezane stroške, kot je klanje, varna odstranitev trupov in stroški diagnostike, ter 6,9\% (535.000) nadomestil za izpad proizvodnje. Povprečni stroški za žival, ki je bila pozitivna za BSE, so znašali 258.400 evrov in za žival iz črede z živaljo, ki je bila pozitivna za BSE, 1.827 evrov. V kafileriji, ki je bila odgovorna za klanje okuženih žvali in živali iz čred, kjer je bila ugotovljena okužba, ter za varno odstranitev trupov, je bilo med marcem 2003 in marcem 2009 predelanih 2.342 ton surovin, kar je stalo 363.777 evrov. Dejstvo, da sta bila zadnja dva primera BSE v letu 2009, nakazuje trend eradikacije bolezni, kar je v skladu s stanjem v drugih državah EU.

Ključne besede: govedoreja / govedo / nalezljive bolezni / goveja spongiformna encefalopatija / BSE / ekonomika / stroški / povračilo stroškov / Češka

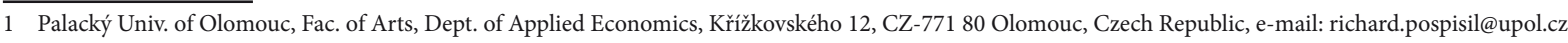




\section{INTRODUCTION}

For more than two decades, the European beef demand was affected by the existence of bovine spongiform encephalopathy (BSE) because of its potential danger to human health. The bovine spongiform encephalopathy (BSE) is an infectious disease caused by prions and was first detected in Great Britain in 1985/1986. In 1988, it was ascertained that the major source of infection was the use of meat and bone meal from the fallen stock animals (Wilesmith et al., 1988). In the Czech Republic, feeding meat and bone meal to ruminants was banned in 1991 (Anonym, 1991).

In the industrialized countries, for the sake of public health cattle slaughtered at 30 months and older was examined for the presence of priors in the brain tissue. In the Czech Republic, the regular examination of animals came into effect on 1st February 2001 and, by $31^{\text {st }}$ December 2014, a total of 1879749 cattle were examined, of which 30 animals were tested positive. Only two outbreaks of the bovine spongiform encephalopathy in 2009 and no case of the BSE within the last five years confirm that in the Czech Republic the disease incidence has definitely a decreasing trend, which is in agreement with the situation in the other EU countries. Because of 30 positive BSE findings, the total of 4243 cows were killed and their carcasses were destroyed. The animals selected to be killed in relation to each BSE occurrence constitute a cohort, which is a group of animals born in the same herd within 12 months preceding or following the date of birth of the affected bovine animal.

Nowadays according to rules of World Organization for Animal Health, each of 180 member countries registered for this organization has assigned a risk status with the degree of risk of BSE. As the official BSE status of a country or zone is determined based on an overall assessment of risk, the occurrence of a new BSE case implies a re-assessment of the official risk status only in the event of a change in the epidemiological situation indicating failure of the BSE risk mitigating measures in place.

Member countries recognised as having a negligible BSE risk in accordance with Chapter 11.4. of the Terrestrial Code of World Organization for Animal Health shows Table 1.

According to Regulation EU No. 2013/76/EU (from $4^{\text {th }}$ February 2013) it is not necessary to investigate in healthy animals in these countries (from $1^{\text {st }}$ July 2013). Table 2 shows countries with controlled BSE risk that are required to test all animals aged over 30 months.

In the Czech Republic, the procedure for the destruction of the killed animals developed over years. At the first, 2001 BSE occurrence, the animals were killed on the farm and buried within its boundary. However, this proved difficult in terms of hygiene and sanitation and was ethically unacceptable. Therefore, on the following five occasions, the animals were killed and their carcasses disposed of at the regular rendering plants. This, however, carried a risk of contaminating both the premises and products and thus, in 2003, the rendering plant Asanace Žichlínek Ltd. was assigned by the State Veterinary Administration to become an institution specialized in killing all the BSE suspected animals, and in processing and disposing of their carcasses in the following years. The meat and bone meal produced was subsequently incinerated in cement works.

In accordance with the EU common Agricultural Policy and farming promotion, the EU provides financial compensations to farmers who have suffered losses due to the BSE. Their allocation is regulated by the Act no. 166/1999 on Veterinary Care and on Amendment of Certain Related Acts (Veterinary Act), with particulars given in the Title IX Compensation of Costs and Losses Incurred in Connection with Dangerous Contagious Diseases (Anonym, 1999). This defines reimbursements to farmers whose cattle herds have been affected by the transmissible diseases specified in the Annexes 3 and 4

Table 1: Negligible BSE risk countries

Preglednica 1: Države z zanemarljivim tveganjem za BSE

\begin{tabular}{|c|c|c|c|c|}
\hline Argentina & Cyprus & Ireland & Netherlands & Slovenia \\
\hline Australia & Czech Republic & Izrael & New Zealand & Sweden \\
\hline Austria & Denmark & Italy & Norway & Switzerland \\
\hline Belgium & Estonia & Japan & Panama & United States \\
\hline Brazil & Finland & Korea (Rep. of) & Paraguay & Uruguay \\
\hline Bulgaria & France & Latvia & Peru & \\
\hline Chile & Hungary & Lichtenstein & Portugal & \\
\hline Colombia & Iceland & Luxembourg & Singapore & \\
\hline Croatia & India & Malta & Slovakia & \\
\hline
\end{tabular}


Table 2: Controlled BSE risk countries

Preglednica 2: Države, ki obvladujejo tveganje BSE

\begin{tabular}{llll}
\hline Canada & Germany & Nicaragua & Spain \\
Chinese Taipei & Lithuania & Poland & United Kingdom \\
Costa Rica & Mexico & Romania & \\
\hline
\end{tabular}

occurrence in Czech herds. In addition, the EU legislation concerning this issue was analysed and compared with the relevant legislation of the Czech Republic.

The method of economic evaluation was the analysis of statistical data related to the costs of the BSE eradication in the

to this Act. For 62 specified dangerous transmissible diseases, it outlines the indemnity strategies and the general itemisation of the compensation. The Czech legislation is in full agreement with the Regulation No. 999/2001 of the European Parliament and of the council, of 22nd May 2001, laying down the rules for the prevention, control and eradication of certain transmissible spongiform encephalopathies, as amended (Pospísil, 2008).

To provide a deeper insight into the legal and economic aspects associated with the BSE in the Czech Republic, the first part of the study was focused on the evaluation of the indemnity policy and quantification of reimbursements provided for farmers according to the Veterinary Act in the period from 2001 to 2014. The total costs were itemised and the cost items broken down to cover the individual operations the farmers were responsible for in the BSE management and for which they were subsequently reimbursed.

In the second part, my aim was to calculate the costs related to the killing and disposal of the animals brought to the rendering plant Asanace Žichlínek Ltd. between October 2003 and 2009. This calculation ends in 2009, because after this year there was no occurrence of BSE in the Czech Republic and no kiliing and disposal of animals in this rendering plant.

\section{MATERIAL AND METHODS}

The chief method used in the first part was the evaluation of legal rules, i.e. legal acts, regulations and implementing provisions, and their application to the BSE
Czech Republic; this information was provided by the Ministry of Agriculture of the Czech Republic (Saksún, 2008). Subsequently, the data was related to the individual cost compensation items, as specified by the Veterinary Act.

The analysis presented in the second part was based on account records provided by the Asanace Žichlínek Ltd. (Nicák, 2008). It included an evaluation of the whole process consisting of animal killing, carcass mechanical processing, heat treatment, sterilisation, drying, hammer-mill pressing and pulverisation, and dispatching of the processed material. The costs of transporting the animals to be killed at the rendering plant were not included. They were born by the farmers who were subsequently reimbursed by the Ministry of Finance in accordance with the Veterinary Act.

\section{RESULTS}

\subsection{PART 1. ECONOMIC EVALUATION OF LOSS COMPENSATIONS}

The reimbursements for the 2001-2014 periods were itemised, analysed and finally summarised.

Table 3 shows the compensations for all costs spent in relation to the BSE between 2001 and 2014. A total of 30 animals tested BSE-positive and, consequently, 4243 animals coming from 141 herds were killed due to the constitution of cohorts. The total of compensations in this period reached EUR 7752000 . The average occurrence was 2.14 BSE-positive animals per year, the average

Table 3: Total costs (in EUR thousand) associated with 30 BSE cases in the period 2001 to 2014

Preglednica 3: Skupni stroški (v tisočih evrov), povezani s 30 primeri BSE v obdobju 2001 do 2014

\begin{tabular}{|c|c|c|c|c|c|c|c|c|c|c|}
\hline Period & $\begin{array}{l}\text { Number } \\
\text { of herds } \\
\text { by cohort } \\
\text { size }\end{array}$ & $\begin{array}{l}\text { Number } \\
\text { of animal } \\
\text { killed }\end{array}$ & $\begin{array}{l}\text { Value of } \\
\text { animals }\end{array}$ & Killing & $\begin{array}{l}\text { Safe carcas } \\
\text { disposal }\end{array}$ & $\begin{array}{l}\text { Examina- } \\
\text { tion for } \\
\text { BSE }\end{array}$ & $\begin{array}{l}\text { Related } \\
\text { costs }^{*}\end{array}$ & $\begin{array}{l}\text { Observ. } \\
\text { of emerg. } \\
\text { veter. } \\
\text { measur. }\end{array}$ & $\begin{array}{l}\text { Non- } \\
\text { material } \\
\text { production }\end{array}$ & Total \\
\hline 2001 & A. 109 & 219 & 383.4 & 8.6 & 39.9 & 6.0 & 3.8 & 0.0 & 5.0 & 446.6 \\
\hline to & B. 17 & 854 & 1164.5 & 16.2 & 90.1 & 34.7 & 6.3 & 4.0 & 97.4 & 1413.2 \\
\hline \multirow[t]{2}{*}{2014} & C. 15 & 3170 & 4910.1 & 55.1 & 321.2 & 130.8 & 27.0 & 15.3 & 432.6 & 5892.1 \\
\hline & $\sum \quad 141$ & 4243 & 6458.0 & 79.9 & 451.2 & 171.5 & 37.1 & 19.3 & 535.0 & 7752.0 \\
\hline
\end{tabular}

$\mathrm{A}=1-10$ animals in a cohort; $\mathrm{B}=11-100$ animals in a cohort; $\mathrm{C}>100$ animals in a cohort

* Costs related to killing and safe disposal of carcasses and farm decontamination 
costs per 1 BSE-positive animal were EUR 258400, and the average costs per 1 cohort of animals (killing and carcass disposal) were EUR 1827.

Of these, $83.3 \%$ (EUR 6458000) were compensations for the value of the killed animals, $9.7 \%$ (EUR 752000) for the related costs, i.e., killing, safe disposal of the carcasses and examination for the BSE, and $6.9 \%$ (EUR 535000) for the losses due to the non-materialised production.

The number of cohorts is not in agreement with the total of 141 herds affected, as shown in Table 3. This is because there were instances when an animal from the original cohort was transferred or sold to another herd. Its new keeper, having to comply with the Emergency Veterinary Measures, then had this cows killed and thus one cow was reported in association with two or more herds.

\subsection{PART 2. EVALUATION OF THE COSTS AS- SOCIATED WITH ANIMAL KILLING AND CARCASS PROCESSINGAT THE ASANACE ŽICHLÍNEK LTD.}

In the period from October 2003 to the end 2014, a total of 3793 cattle were killed and their carcasses destroyed and disposed of at the rendering plant. This included 701 cows in 2003; 1167 in 2004; 1262 in 2005; 288 in 2006; 131 in 2007, 23 in 2008 and 221 animals in 2009. In the terms of the cohort size, the largest one $\left(7^{\text {th }}\right)$ included 875 cows, the smallest $\left(27^{\text {th }}\right)$ had only three animals. The average was 126 animals per 1 cohort. The animals of $27^{\text {th }}$ cohort derived from the BSE case detected on 19th December 2007 were gradually identified and destroyed early in 2008. The selected economic items and their distribution in the years 2003 to 2009 are shown in Table 4. Table ends in 2009, because after this year there was no occurrence of BSE in the Czech Republic.

According to Table 4 a total of 2342 tons of raw material was processed at costs ranging from EUR 0.15 to EUR 0.30 per $1 \mathrm{~kg}$ between 2003 and 2009. The gradual increase in the cost per $1 \mathrm{~kg}$ was due to a rise in operation costs including higher wages and increased energy prices. Based on the cost per $1 \mathrm{~kg}$ processed material, the total costs associated with animal killing and carcass disposal reached EUR 53807 in 2003, EUR 91911 in 2004, EUR 145684 in 2005, EUR 35379 in 2006, EUR 14670 in 2007, EUR 3534 in 2008 and EUR 18792 in 2009. The total costs for the whole period of 2003-2009 amounted to EUR 363777.

\section{DISCUSSION}

Due to early and stringent veterinary precautions and the ban on feeding meat and bone meal (MBM) to cattle in 1991, the first case of the BSE in the Czech Republic was detected in 2001. The most probable cause was an indirect contamination of cattle feed with the imported MBM or with the MBM intended for feeding pigs and poultry and allowed for use before 2003 (Semerád, 2007). In the period from $1^{\text {st }}$ February 2001 to $31^{\text {st }}$ December 2014, 30 BSE-positive cases were identified by the active monitoring for the BSE involving 1879479 cows. The detection was effective thanks to the well coordinated laboratory diagnostic procedures carried out in the laboratories of the State Veterinary institutes in Prague, Jihlava and Olomouc.

To reduce the economic impact of the BSE on farmers, legal means have been established to reimburse farmers for the losses both direct and related. The latter involve costs of the examination for the BSE, transport of animals to a specialised rendering plant, their killing and safe disposal of their carcasses, and cleaning and disinfection of the holding and its equipment, though this procedure is questionable, because the BSE is not a truly contagious disease. In addition, the farmer is reimbursed for losses due to the non-materialised production. However, not all these compensations can completely cover the costs incurred in relation to the BSE.

In the first place, the producer-consumer relations, usually taking a long time to establish, are destroyed and the return to the market is difficult; also, large costs are necessary to build up the herd again. These costs are difficult to calculate and their compensation cannot be claimed because they are not treated by the legislation. A BSE incident is also associated with several adverse consequences, such as loss of jobs in an agricultural enterprise, which can have a deep impact on rural populations. The ensuing problems in the broadest sense of the word can partly be eased by the commercial insurance policy. The experience showed that most of the farmers were insured. Any payment of insurance benefit has no effect on the amount of cost compensation based on the Veterinary Act. Since a farmer-insurance company relationship is a business one, it was not possible to find out the information on benefit payments and to include it in this study.

The total amount of compensations paid was EUR 203704 in 2001, EUR 59259 in 2002, EUR 1740741 in 2003, EUR 1474074 in 2004, EUR 3403704 in 2005 and EUR 411111 in 2006. In 2007, it was only EUR 6278, because the $27^{\text {th }}$ case was an eleven-year-old cow whose cohort included only three animals left due to slaughtering of the other cows. Compensations provided in rela- 
Table 4: Selected costs of BSE-related cattle disposal at the rendering plant Asanace Žichlinek Ltd. and their distribution over the period 2001 to 2009

Preglednica 4: Izbrani stroški, povezani z odstranjevanjem z BSE okuženih živali v kafileriji Asanace Žichlínek Ltd., in njihova porazdelitev v obdobju 2001 do 2009

\begin{tabular}{|c|c|c|c|c|c|c|}
\hline & & Quarter 1 & Quarter 2 & Quarter 3 & Quarter 4 & Total \\
\hline \multirow[t]{4}{*}{2003} & EUR/kg & & & & 0.15 & \\
\hline & kg processed & & & & 415080 & 415080 \\
\hline & animal killed & & & & 701 & 701 \\
\hline & total costs & & & & 53807 & 53807 \\
\hline \multirow[t]{4}{*}{2004} & EUR/kg & 0.15 & 0.15 & 0.15 & 0.15 & \\
\hline & kg processed & 362869 & 60800 & 190951 & 94410 & 709030 \\
\hline & animal killed & 607 & 101 & 310 & 149 & 1167 \\
\hline & total costs & 47039 & 7881 & 24753 & 12238 & 91911 \\
\hline \multirow[t]{4}{*}{2005} & EUR/kg & 0.17 & 0.17 & 0.17 & 0.17 & \\
\hline & kg processed & 257220 & 293200 & 146800 & 115200 & 812420 \\
\hline & animal killed & 397 & 454 & 240 & 171 & 1262 \\
\hline & total costs & 42870 & 54296 & 27185 & 21333 & 145684 \\
\hline \multirow[t]{4}{*}{2006} & EUR/kg & 0.19 & & & 0.19 & \\
\hline & kg processed & 158426 & & & 32620 & 191046 \\
\hline & animal killed & 236 & & & 52 & 288 \\
\hline & total costs & 29338 & & & 6041 & 35379 \\
\hline \multirow[t]{4}{*}{2007} & EUR/kg & 0.19 & & & & \\
\hline & kg processed & 79220 & & & & 79220 \\
\hline & animal killed & 131 & & & & 131 \\
\hline & total costs & 14670 & & & & 14670 \\
\hline \multirow[t]{4}{*}{2008} & EUR/kg & 0.25 & & & & \\
\hline & kg processed & 14680 & & & & 14680 \\
\hline & animal killed & 23 & & & & 23 \\
\hline & total costs & 3534 & & & & 3534 \\
\hline \multirow[t]{4}{*}{2009} & EUR/kg & 0.30 & & & & \\
\hline & kg processed & 62660 & & & & 62660 \\
\hline & animal killed & 221 & & & & 221 \\
\hline & total costs & 18792 & & & & 18792 \\
\hline \multicolumn{3}{|c|}{ Total costs for 2003 to 2009} & & & & 363777 \\
\hline
\end{tabular}

tion to the $28^{\text {th }}$ BSE-positive case detected on $19^{\text {th }}$ December 2007 were paid in March 2008 and reached EUR 50222 . The last two cases of BSE occurrence in 2009 cost 402 907. The total costs associated with the BSE occurrence in the Czech Republic amounted to EUR 7752000. The average costs per 1 BSE-positive animal were EUR 258400 and the average costs per 1 cohort of animals (killing and disposal of the carcasses) were EUR 1827.

To ease the negative economic impacts of the BSE, the EU provides financial support for all member states. For instance, in 2007 the Czech Republic received EUR
1640000 for the active monitoring and EUR 2500000 for the eradication (EU-Dg-SAnco, 2006).

It is interesting that the amounts of reimbursement presented in the international literature are reported only as the total costs per certain period, including the data from the Great Britain that suffered most. The calculation of cost compensations is based on tables prepared in advance in which, for each cattle age category, the amount of compensation is given without any respect to the animal's actual productivity (Defra, 2007). The British government study has reported that the total net cost 
of the BSE crisis to the Exchequer by the end of the fiscal year 2001/2002 reached $€ 4.2$ billion, to which the EU contributed $Ł 487$ million, which is $11.6 \%$ (Brinkle, 2002). It is evident that this high sum of money was relevant to the exceptionally high number of the BSE-positive cows that had exceeded 187000 animals by that fiscal year. This sum also included $€ 720$ million to compensate for the loss of markets in the EU countries, because the European Commission banned beef export in March 1996 (in the USA, import of British beef was banned in the late 1980s). The beef production accounts for about $0.5 \%$ of the British gross domestic product and the British beef industry has over 130000 employees. With the decrease in beef meat prices, the prices of all other kinds of meat increased in the Great Britain. This chiefly concerned poultry and lamb meat, which increased in price approximately by $5 \%$, with pork price remaining generally unchanged (Leeming and Turner, 2004).

In Northern Ireland, the beef producing industry employs over 5000 workers and the additional 600000 are employed in the related industrial branches (Caskie et al., 1998). Thus, the rate of employment in this industry has a deep social impact. The costs of re-qualification for workers who had lost their jobs due to the reduced beef production were estimated to be $7.9 \%$ of all costs related to the BSE crisis (Muth et al., 2005).

This study paid attention to the costs of animal killing and their carcass disposal in the rendering plant specialised for this purpose. The evaluation was based on the cost per $1 \mathrm{~kg}$ of the processed material, which ranged from EUR 0.15 in 2003 to EUR 0.30 in 2009. Between March 2003 and the end 2009, the total of 3793 bovine animals associated with the BSE occurrence were killed there and their carcasses were destroyed and disposed of; this accounted for 2342 tons of the processed material. The total costs for the whole period amounted to EUR 363777 . The considerable increase in costs during this period is in agreement with the inflation development (wagepush, energy price increase) in the domestic economy and is also related to the increased financial demands for the hygienic and technological quality of the rendering plant operation (septic and aseptic units, disinfecting fords, separation of processing routes) after the Czech Republic joined the EU.

Costs described here did not include the costs of transporting the animals to be killed to the rendering plant. These were covered by the farmer who was subsequently reimbursed by the Ministry of Finance in accordance with the Act no. 166/1999 on Veterinary Care and on the Amendment of Certain Related Acts. The costs greatly varied depending on the distance between the farm and the rendering plant and on whether the farmers had their owntransporting facilities or had to hire it.
In one instance, no long-distance transport was needed. It occured when the first BSE case was discovered in 2001 in the village of Dušejov in the Jihlava district. All 134 cows of the cohort were killed on the farm and buried in its vicinity. The carcasses were placed four metres deep in the ground and were covered up with a 1.5-2 m layer of soil (Meloun, 2006). Although this method of disposal may seem complicated, the total costs were only EUR 2866 (hydrogeological expert report EUR 300, wages EUR 478, local transport EUR 1593, fencig EUR 495) (Saksún, 2008), which was much less than what the process of disposal would have cost in a rendering plant.

However, for the public health and environmental reasons it was not possible to continue with this method of disposal. Moreover, the cohorts derived from the later BSE cases were larger in size that the first cohort buried in Dušejov. For instance, the cohort from the $7^{\text {th }}$ case in 2003 had 875 cows and that from $22^{\text {nd }}$ case in 2005 had 333 cows, and the burial of so many animals would not have been feasible.

The rendering process produces meat and bone meal; one kilogram of raw material gives 0.28 to $0.29 \mathrm{~kg}$ of it. In addition, 0.08 to $0.09 \mathrm{~kg}$ of animal fat is obtained; the residual fat content in meat and bone meal is $13 \%$ to $18 \%$ and residual moisture is $2.8 \%$.

The meat and bone meal produced is transported to cement works for incineration at the temperature of about $1200^{\circ} \mathrm{C}$. One kilogram of meat and bone meal gives about $0.25 \mathrm{~kg}$ ash. By the process carried out at the rendering plant and by the subsequent incineration in a cement factory, 30 to $40 \mathrm{~kg}$ ashes are produced. The ashes are included in the cement production and become a part of the final product. Considering that the total number of cows killed and disposed of at the rendering plant Asanace Žichlínek was 3793, the total amount of ashes produced in the cement works was 637 tons.

The rendering plant paid 5 cents the cement works for $1 \mathrm{~kg}$ meat and bone meal to be incinerated, and claimed an equal compensation from the Ministry of Agriculture of the Czech Republic. The funds to cover the expenses related to the disposal of meat and bone meal had been included in the state budget (the "general Treasury Administration" chapter) until 2007. Since 2007, the funds have no no longer been available and the meat and bone meal have been incinerated in the cement works free of charge. However, the cement works can utilize the caloric power of the meat and bone meal, because its $18 \mathrm{MJ}$ per $\mathrm{kg}$ equals to the fuel efficiency of $1 \mathrm{~kg}$ lignite (Anonym, 2008). Considering that the average price of 1 ton of lignite is EUR 125, the 637 tons of burnt meat and bone meal contributs about EUR 79625 to the cement factory's budget. 


\section{CONCLUSION}

Between February 2001 and the end of 2014, the total of 1879479 cows were examined and 30 cases of the BSE were detected. Consequently, 4243 cows in cohorts were killed and their carcasses were safely disposed of. The total of compensations in this period reached EUR 7752000 . Of these, $83.3 \%$ (EUR 6458000) were compensations for the value of the killed animals, $9.7 \%$ (EUR $752000)$ for the related costs, i.e., killing, safe disposal of carcasses and examination for the BSE, and $6.9 \%$ (EUR $535000)$ for the losses due to the non-materialised production. The average costs per $1 \mathrm{BSE}-$ positive animal were EUR 258400 and the average costs per 1 cohort of animals were EUR 1 827. In the rendering plant in Žichlínek responsible for killing of the infected and cohort animals and safely disposing of their carcasses, the total of 2342 tons of raw material were processed between March 2003 and 2009, and this cost EUR 363777.

\section{ACKNOWLEDGEMENTS}

Work on this article was supported by the grant from Philosophical Faculty of Palacký University, IGA FF_2015_014, Continuities and Discontinuities of Economy and Management in the Past and Present.

\section{REFERENCES}

Anonym. 1991. Vyhláška č. 413/1991 Sb., o registraci některých druhů krmiv, jejich dodavatelů a o odborné státní kontrole (Decree No. 413/1991 Sb., about registration of feed, its suppliers and specific state control). Mze ČR, Praha.
Anonym. 1999. Zákon č. 166/1999 o veterinární péči a o změně některých souvisejících zákonů (Act no. 166/1999 coll. on Veterinary Care and on Amendment of Certain Related Acts). Mze ČR, Praha.

Anonym. 2008. Protokol č. 383/2007/PoV (record no. 383/2007/ PoV). Laboratoř paliv, odpadů a vod VÚHU, a.s. Most.

Brinkle J. 2002. Impact of BSE on the UK Economy. National Audit office, NC, USA.

Caskie P., Moss J.E., Davis J. 1998. The beginning of the end or the end of the beginning for the BSE crisis? Food Policy, 23: 231-240. http://dx.doi.org/10.1016/S0306-9192(98)000359

EU-Dg SAnco E.2. 2006. Hygiene and control measures. Annual Activity report: $42-43$

DEFRA. 2007. Compensation for Bovine TB, BSE, Brucellosis and Enzootic Bovine Leukosis. Information Bulletin, ref: $238 / 07$

Leeming J., Turner P. 2004. The BSE crisis and the price of red meat in the UK. Applied Economics, 36: 1825-1829. http:// dx.doi.org/10.1080/0003684042000227868

Meloun V. 2006. Výskyt BSE v České republice do roku 2006 (BSE occurrence in the Czech Republic till 2006). [Dissertation Thesis.] Státní veterinární správa Čr, Brno.

Nicák J. 2008. Osobní sdělení, [Personal communication]. Účetní doklady Asanace, spol. s r.o. Žichlínek.

Pospíšil R. 2008. Hlavní zásady a struktura náhrad poskytovaných chovatelům $s$ výskytem bovinní spongiformní encefalopatie $\mathrm{v}$ chovech skotu (Majority of compensations to Breeders with BSE occurrence in breeding cattle). Acta Universitatis Agriculturae et Silviculturae Mendeleianae Brunensis, 56: 257-261; iSSn 1211-8516.

Saksún J. 2008. Informace Ministerstva zemědělství ČR k výskytu BSE v ČR (Ministry of Agriculture information on BSE occurrence in the Czech Republic). Mze, ČR.

Semerád Z. 2007. Osobní sdělení, [Personal communication]. SVS, ČR.

Wilesmith J.W., Wells G.A.H., Cranwell M.P., Ryan J.B.M. 1988. Bovine spongiform encephalopathy: epidemiological studies. Veterinary record, 123: 638-644; ISSN 0042-4900. Arrived on 10th November 2008. 